\title{
Field Utilization of Dried Water Hyacinth for Phosphorous Recovery from Source-Separated Human Urine
}

\author{
Boqi Weng ${ }^{1}$, Junli Zhou ${ }^{2,3}$, Siping Zheng ${ }^{4}$, Xiuxia Chen ${ }^{4}$, Weiguang Zhang ${ }^{1}$, Qin Huang ${ }^{4 *}$ \\ ${ }^{1}$ Agricultural Ecology Institute, Fujian Academy of Agricultural Sciences, Fuzhou, China; ${ }^{2}$ School of Chemical Engineering, Tianjin \\ University, Tianjin, China; ${ }^{3}$ Department of Chemical and Biomolecular Engineering, The Hong Kong University of Science and \\ Technology, Hong Kong, China; ${ }^{4}$ Biotechnology Institute, Fujian Academy of Agricultural Sciences, Fuzhou, China. \\ Email: *leerfu@163.com
}

Received May $11^{\text {th }}, 2012$; revised June $13^{\text {th }}, 2012$; accepted July $13^{\text {th }}, 2012$

\begin{abstract}
This research demonstrated the feasibility of converting source-separated human urine into a solid fertilizer by means of continuous absorption and solar thermal evaporation using dried water hyacinth as adsorbent. In a preliminary experiment, the dried petioles of water hyacinth (DWH) absorbed urine in a mean rate of $18.78 \mathrm{ml} \cdot \mathrm{g}^{-1}$ within $7 \mathrm{~d}$, retrieving about $3.46 \%$ urine dissolved solids (UDS). In an advanced experiment, the DWH's capacity of urine absorption declined from an initial $2.73 \mathrm{~L} \cdot \mathrm{kg}^{-1} \cdot \mathrm{d}^{-1}$ to $0.68 \mathrm{~L} \cdot \mathrm{kg}^{-1} \cdot \mathrm{d}^{-1}$, with a requirement of material change in about 25 effective days and an average ratio of $25(\mathrm{~L})$ to $1(\mathrm{~kg})$. Phosphorus $\left(\mathrm{P}_{2} \mathrm{O}_{5}\right)$ concentration in the adsorbent increased from $0.46 \%$ (material baseline) to $3.14 \%$ (end product), suggesting a satisfactory recovery of the element. In field application, the urine was discharged, not in wet weather, onto the DWH via a tube connected to a waterless urinal. There are several ways to use the UDS-DWH as $\mathrm{P}(\mathrm{K})$-rich fertilizer, e.g., making soluble fertilizer for foliage spraying to encourage prolific flowering and fruiting. Apparently, utilization of water hyacinth waste to recover dissolved plant nutrient elements from source-separated urine will benefit the environment in a wide range of perspectives. The herein innovative use of water hyacinth is also expected to be useful in the recycling of certain dissolved hazardous materials.
\end{abstract}

Keywords: Dried Water Hyacinth; Urine Dissolved Solids; Phosphorus Recovery; Waste Utilization; Source-Separated Human Urine

\section{Introduction}

Dried petioles of water hyacinth (Eichhornia crassipes) were found useful for phosphorus removal from highly eutrophic water bodies [1,2]. In nature, phosphorus in soil is taken up by plants and then moves through the food chain. It is released back to the land when plant or animal matter decomposes. The cycle has been, however, disrupted as a result of man's over-exploitation. Now many soils are fertilized using the elements from phosphate rocks. Phosphorus overloading has become a very high profile water quality issue. Meanwhile, the viable commercial reserve of phosphate is being depleted and estimated to run out within $50-100$ years [3].

Hence there is a growing interest in phosphorus recovery from source-separated human urine for agriculture use [4]. It is estimated that in 2050 the available phosphorus from urine will increase to 2.16 million MT [5]. Various ecosan technologies have been invented to meet the objective [6,7], but most of them are either too

"Corresponding author. expensive, impractical or both for developing countries. There are other options available for phosphorous recovery from source-separated human urine, e.g., evaporation, precipitation, ammonia stripping and struvite crystallization $[8,9]$. Among the variety of techniques being studied, evaporation is currently the most feasible approach for agricultural zones, where solar radiation is an abundant energy source while convenient organic fertilizers are heavily demanded.

The air spaces in the petioles of water hyacinth are walled by single layered parenchyma cells, which give rise to a large surface area for fast evaporation as well as efficient moisture absorption and dissolved solids (DS) adsorption. This work focused on the practical aspects of using dried water hyacinth (DWH) as a natural adsorbent to retrieve urine dissolved solids (UDS), phosphorous in particular, through repeat absorption and solar thermal evaporation. Field application was performed at a guest farm to satisfy the goals. Some basic physical properties of the DWH material, such as water absorption capacity, porosity, relative density and the retention of dissolved 
solid (i.e., $\mathrm{KH}_{2} \mathrm{PO}_{4}$ ), were also investigated as a prelude to studying the subject.

\section{Material and Methods}

\subsection{Material Preparation}

The water hyacinth waste was collected from a wastewater treatment lagoon at the Torch Park, Xiamen, China. The petioles, with an average length of $70 \mathrm{~cm}$, were sliced lengthwise using a cutting machine and sun-dried for storage.

\subsection{Water Absorption and Evaporation}

Water holding capacity (WHC) of the DWH was determined using a method modified from the ASTM D7367 (2007). $1.00 \mathrm{~g}$ of the specimen was submerged in $90 \mathrm{ml}$ distilled water $(\mathrm{dw})$ in a $100 \mathrm{ml}$ screw-cap glass bottle and weighed after 2, 6, 12, 24 and $36 \mathrm{~h}$, respectively. They were drained on a sieve for $3 \mathrm{~min}$ and weighed to the nearest $0.01 \mathrm{~g}$ using an electronic balance. The mean value of three replicates was used to calculate water absorption rate [Equation (1)] as well as the value of WHC [Equation (2)].

$$
\begin{gathered}
\operatorname{Absorption}(\%)=\left[\left(W_{w}-W_{d}\right) / W_{d}\right] \times 100 \\
\operatorname{WHC}(\%)=\left[\left(W_{s}-W_{d}\right) / W_{d}\right] \times 100
\end{gathered}
$$

where $W_{d}, W_{w}$ and $W_{s}$ denote, respectively, the initial dry weight (i.e., $1.00 \mathrm{~g}$ ), the wet weight and the saturated weight of the material.

The material porosity was estimated following a method of liquid immersion technique [10] with modification. The specimens were oven dried $24 \mathrm{~h}$ at $45^{\circ} \mathrm{C}$, weighed, and placed in a $30 \mathrm{~cm} \times 30 \mathrm{~cm}$ plastic vacuum bag. The bag was vacuumized for $20 \mathrm{~min}$ and then injected with $\mathrm{dw}$ to cover the specimen. The immersion lasted for $60 \mathrm{~min}$ and the specimen was subjected to an immediate weighing. A dry towel was placed on the balance to collect drained water. The percentage porosity was calculated by Equation (3).

$$
\operatorname{Porosity}(\%)=\left[\left(W_{w}-W_{d}\right) / W_{w}\right] \times 100
$$

where $W_{d}$ and $W_{w}$ denote, respectively, the initial dry weight and the final wet weight of the specimen. The average volume of $1.00 \mathrm{~g}$ DWH was estimated by measuring the volume of water expelled when the specimen was submerged into $80.0 \mathrm{ml}$ of dw contained in a $100 \mathrm{ml}$ measuring cylinder $( \pm 1.0 \mathrm{ml})$. All data were expressed as the mean of three replicates.

The efficacy of DWH on water evaporation was tested in the following procedures. $1.00 \mathrm{~g}$ of DWH specimens was cut into about $1 \mathrm{~cm}$ long and laid on a piece of filter paper in a plastic sieve. $3 \mathrm{ml}$ of $\mathrm{dw}$ was dropped onto the specimen through a $1.0 \mathrm{ml}$ medical syringe to avoid excessive water dispensing. The specimens were then exposed to sunlight for evaporation. On day one (from 9:00 am to $6: 00 \mathrm{pm}$ ), a total of $12.0 \mathrm{ml} \mathrm{dw}$ was consumed in four wet/dry cycles. On day two, the specimen absorbed a total of $10.0 \mathrm{ml} \mathrm{dw}$. The average rate of absorption/ evaporation for the material was shown to be $\sim 11 \mathrm{ml} \mathrm{dw}$ $\mathrm{g}^{-1} \cdot \mathrm{d}^{-1}$.

\subsection{Dissolved Solid Adsorption in DWH}

This experiment was carried out to evaluate DS retention by DWH through absorption/evaporation cycling. $3.00 \mathrm{~g}$ of the DWH specimens were cut into approximately $4 \mathrm{~cm}$ long and placed on a plastic plate. A solution of $10 \%$ (w/v) $\mathrm{KH}_{2} \mathrm{PO}_{4}(\mathrm{AR})$ was transferred into the specimens from a $5.0 \mathrm{ml}$ syringe. The wet/dry cycle was repeated until the salt precipitates covered the surface of the adsorbents, which were then weighed for the value of the observed final weight $\left(O W_{f}\right)$. The expected final weight $\left(E W_{f}\right)$ of the $\mathrm{KH}_{2} \mathrm{PO}_{4}$-bearing specimen was calculated using Equation (4).

$$
E W_{f}(g)=W_{C 1}-W_{C 2}+W_{i}
$$

where $W_{C 1}$ and $W_{C 2}$ indicate respectively the amount of solid $\mathrm{KH}_{2} \mathrm{PO}_{4}$ supplied in total and that collected from the plate at the end of the experiment. $W_{i}$ represents the initial weight of the DWH specimen (i.e., $3.00 \mathrm{~g}$ ). Data were expressed as the mean $\pm \mathrm{SD}$ and presented as an average of three replicate.

There were two controls. Control 1 duplicated the above procedures except that the solution of $\mathrm{KH}_{2} \mathrm{PO}_{4}$ was replaced by dw. In Control 2, $50 \mathrm{ml}$ of $10 \% \mathrm{KH}_{2} \mathrm{PO}_{4}$ solution was contained in an open $100 \mathrm{ml}$ beaker for evaporation so that weight change between the solid and the precipitate could be measured.

\subsection{Urine Dissolved Solids Adsorption in DWH}

The DWH adsorption of urine dissolved solids (UDS) was investigated in laboratory. The specimens were cut into $1 \mathrm{~cm}$ long and weighed to $1.00 \mathrm{~g}\left(30^{\circ} \mathrm{C}, 64 \% \mathrm{RH}\right)$ in three replicates. Each absorption/evaporation cycle began with the material's absorption of fresh human urine transferred from a $1 \mathrm{ml}$ syringe. Weighing was performed before and after the wetting. Two layers of filter paper were put under the specimen to absorb excess moisture during the procedure and weighed separately after the specimen's removal for sun drying. The urine absorption fraction (UAF) was calculated using Equation (5).

$$
\begin{gathered}
\operatorname{UAF}(w / w)=W_{u} / W_{d} \\
W_{u}=W_{w h}-W_{w p}-W_{d}
\end{gathered}
$$

where $W_{d}$ indicates the weight of specimen before re- 
spective absorptions; $W_{w p}$ and $W_{w h}$ indicate, respectively, the wet weight of filter paper and the wet weight of the filter paper and the specimen as a whole; $W_{u}$ represents the weight of urine absorbed.

\subsection{Urine Phosphorus Recovery in DWH}

A pilot experiment was performed in the summer of 2011 at an apartment with a large eastern balcony. Five plastic sieves, each had an inside dimension of $6 \mathrm{~cm} \times 338 \mathrm{~cm}^{2}$ and contained $\sim 80 \mathrm{~g}$ of DWH, were stacked on top of one another for urine absorption by the DWH. A plastic tray, which contained $\sim 40 \mathrm{~g}$ of the material, was put at the bottom of the stacked sieves to absorb excess moisture. The device was placed on balcony to receive adequate sun exposure and air circulation while avoiding being wet by the rain. At the beginning of the experiment, the DWH materials were absorbed with $1.0 \mathrm{~L}$ fresh urine in a tray to overcome the effect of surface tension. To ensure an adequate absorption throughout, the order of the sieves was changed by moving the topmost to the bottom each time when a new cycle started. Fresh urine was poured slowly and evenly onto the absorbents from the top of the stack usually upon sunrise in the early morning and the midday. The UDS adsorbed DWH (UDS-DWH) was sampled randomly for total phosphorus (TP) determination. The contents of total nitrogen (TN) and potassium $(\mathrm{K})$ were also measured for relevant discussions.

Field application was realized in March 2012 at \#3 Dongshan Guest Farm, Xiamen. The urine was discharged, not in wet weather, onto the DWH via a tube connected to a waterless urinal (Figure 1). 2\% dilute

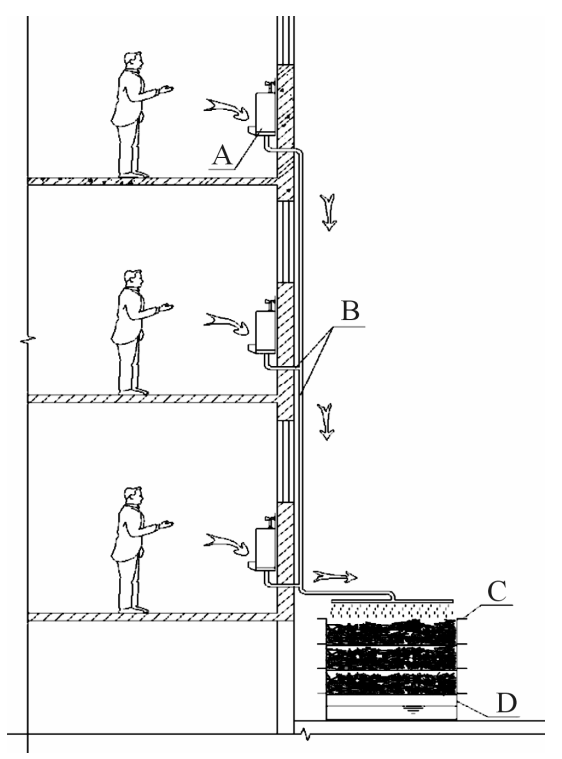

Figure 1. Field utilization of dried water hyacinth for phosphorous recovery from source-separated human urine. A: Male urinal; B: Urine outlet; C: Stacked sieves containing dried water hyacinth petioles; D: Tray for excess urine. acetic acid was used to remove urine odor and spots from the urinal when necessary. Each of the three stacked baskets contained $\sim 6 \mathrm{~kg}$ of the DWH materials. The adsorbents were also laid inside the tray at the bottom.

\subsection{Chemical Analyses}

NPK contents in DWH specimens were measured using the following methods: Determination of total nitrogen content for Compound fertilizers (GB/T8572-2001, PRC), Determination of organic-inorganic compound fertilizers-Part 2: Total phosphorus content (GB/T17767.22010, PRC) and Determination of potassium content for compound fertilizers - Potassium tetraphenylborate gravimetric method (GB/T8574-2010, PRC).

By convention, TP was expressed as $\mathrm{P}_{2} \mathrm{O}_{5}$ concentration in fertilizer and as $\mathrm{PO}_{4}^{3-}$ ion concentration in the urine. To convert $\mathrm{PO}_{4}^{3-}$ concentration to $\mathrm{P}_{2} \mathrm{O}_{5}$, the data were multiplied by a factor of 0.746 .

\subsection{Scanning Electron Microscopy}

DWH specimens adsorbed with either UDS or $\mathrm{KH}_{2} \mathrm{PO}_{4}$ precipitates were mounted onto respective metal stubs and sputter-coated with gold. They were subsequently imaged in a scanning mode using conventional SEM techniques (JEOL/EO JSM-6380, Japan).

\section{Results and Discussion}

\subsection{Water Absorption Capacity}

Figure 2 illustrates result of the present water absorption experiment. On average, it took about $24 \mathrm{~h}$ to saturate a DWH specimen. In the summer (July), the immersion bottle gave foul smell after $24 \mathrm{~h}$, indicating an active microbial growth. Temperature could affect the rate of absorption significantly, e.g., the mean value of WHC was $475 \%$ at $15^{\circ} \mathrm{C} \pm 1{ }^{\circ} \mathrm{C}$, but being $648 \%$ at $30^{\circ} \mathrm{C} \pm 1{ }^{\circ} \mathrm{C}$. Compared with many other plant materials, the present

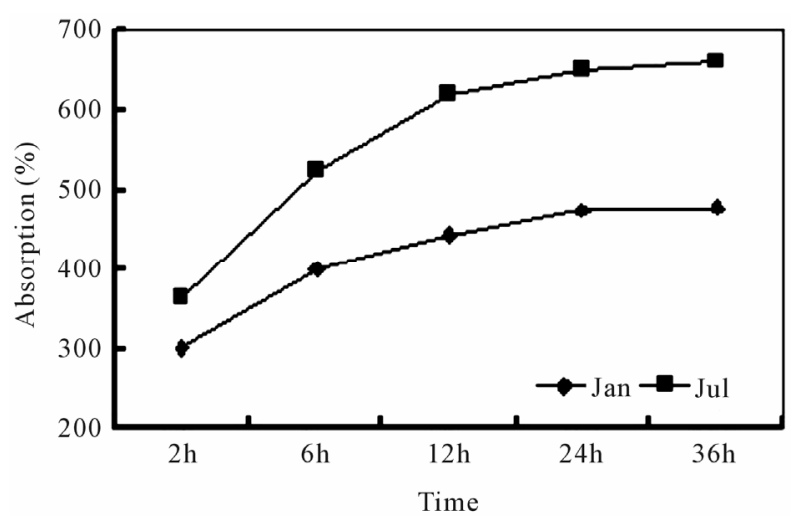

Figure 2. Water absorption rate of DWH. Jul: Data collected in July $2010\left(30^{\circ} \mathrm{C} \pm 1^{\circ} \mathrm{C}\right)$. Jan: Data collected in January $2011\left(15^{\circ} \mathrm{C} \pm 1^{\circ} \mathrm{C}\right)$. 
materials exhibited much greater values of WHC, which were shown to be, e.g., $323.8 \%$ for the threshed oak straw [11], $257 \%$ for the wheat straw and $327 \%$ for coir [12].

The relative mass density of the DWH specimens was measured to be about $7.5 \mathrm{~cm}^{3} \cdot \mathrm{g}^{-1}$ at $31^{\circ} \mathrm{C}, 64 \% \mathrm{RH}$, i.e., roughly $0.01 \mathrm{M}^{3} \cdot \mathrm{kg}^{-1}$. It varied considerably with relative humidity and ambient temperature. For example, a specimen weighed $10.00 \mathrm{~g}$ at $48 \% \mathrm{RH}\left(32^{\circ} \mathrm{C}\right)$ was shown gaining $8.75 \%$ weight at $72 \% \mathrm{RH}\left(32^{\circ} \mathrm{C}\right)$. The mean porosity was shown to be $86.4 \%$ (at $31^{\circ} \mathrm{C}, 64 \% \mathrm{RH}$ ), relatively higher than the values for the fresh petioles, i.e., about $69.6 \%$ - $74.1 \%$ [13].

Rapid water diffusion of plant materials under high temperatures was demonstrated by Zabihzadeh [14]. Several mechanisms have been proposed to explain the temperature effect on liquid movement in porous materials. Weast [15] and Smiles [16] attributed the temperature dependency to the kinematic viscosity and surface tension of water. Grant and Bachmann [17], however, believed that the phenomenon could be affected by either the volume change of water and entrapped air, the interracial tension effects associated with solutes, or the effect of temperature on contact angles.

\subsection{DS Retrieval in DWH}

$10 \% \mathrm{KH}_{2} \mathrm{PO}_{4}$ solution absorbed in DWH evaporated faster than when it was contained in a beaker. The dried DWH became hard as the precipitates accumulated. Under SEM, the precipitated salt appeared to fuse into either a stiff layer covering the pore wall surface or amorphous solids lying on the outside surface of the material (Figures 3(a) and (b)). Hardly any independent crystals were shown held in the pore cavity or the channels.

$\mathrm{KH}_{2} \mathrm{PO}_{4}$ has a specific density of $2.338 \mathrm{~g} \cdot \mathrm{cm}^{-3}$. Its maximum storage in DWH was expected to be $15.15 \mathrm{~g} \cdot \mathrm{g}^{-1}$ at $64 \% \mathrm{RH}, 31^{\circ} \mathrm{C}$, regarding the adsorbent porosity. In the experiment, each of the specimens received $335 \mathrm{ml}$ of $10 \% \mathrm{KH}_{2} \mathrm{PO}_{4}$ solution during 12 sunny days, undertaking 3 cycles $\cdot \mathrm{d}^{-1}$ on average. Upon saturation, the mean storage of $\mathrm{KH}_{2} \mathrm{PO}_{4}$ was about $11.27 \mathrm{~g} \cdot \mathrm{g}^{-1}$ (Table 1), which realized approximately $74.4 \%$ of the assumed capacity. No significant difference was determined between $\mathrm{E} W_{f}$ and $\mathrm{O} W_{f}$ when analyzed using chi-square tests $(\mathrm{p}>0.95)$.

The present results demonstrated the feasibility and effectiveness of using DWH for DS recovery through absorption/evaporation. This innovation can be expected to be useful in the recycling of some dissolved hazardous materials. Meanwhile, the results helps explain why floating water hyacinth straws absorb more phosphorus than the fully hydrated counterparts [2]. Physical adsorption and surface precipitation are regarded as possible mechanisms with respect to the observed phenomena and

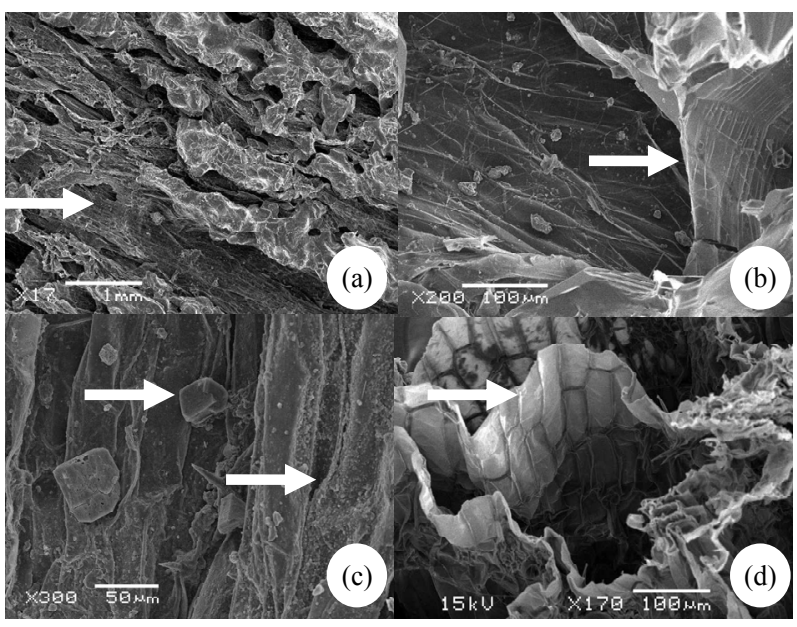

Figure 3. SEM photos of dried water hyacinth petiole tissues. (a) An oblique section covered with precipitated $\mathrm{KH}_{2} \mathrm{PO}_{4}$ salt. Arrow indicates an area without the salt; (b) A cross section showing a stiff layer of $\mathrm{KH}_{2} \mathrm{PO}_{4}$ coating the pore walls; (c) A longitude section showing pore walls deposited with urine paste (lower arrow) and salt crystals (upper arrow); (d) A cross section showing one-cell thick pore walls.

Table 1. Weight change in DWH adsorbed with salt from a $10 \% \mathrm{KH}_{2} \mathrm{PO}_{4}$ solution.

\begin{tabular}{cccccc}
\hline & \multirow{2}{*}{$\begin{array}{c}\text { Experiment } \\
\text { group }\end{array}$} & \multicolumn{2}{c}{ Controls } & & \\
\cline { 3 - 4 } & & $\mathrm{DWH}$ & $\left.\mathrm{KH}_{2} \mathrm{PO}_{4} \mathrm{C}\right)$ & $\mathrm{RH}(\%)$ \\
\hline$W_{i}$ & $3.00 \mathrm{~g}$ & $3.00 \mathrm{~g}$ & $5.00 \mathrm{~g}$ & 31 & 64 \\
\hline$W_{f}$ & $36.80 \pm 0.1538 \mathrm{~g}$ & $3.02 \mathrm{~g}$ & $5.00 \mathrm{~g}$ & 31 & 64 \\
\hline$W_{f}$ & $36.11 \pm 0.01581 \mathrm{~g}$ & & & & \\
\hline
\end{tabular}

$W_{i}$ : Initial weight; $O W_{f}$ : The observed final weight; $E W_{f}$ : The expected final weight.

by reference to metal biosorption in wheat straw and grass [18].

\subsection{UDS and Urine $P$ retention in DWH}

Figure 4 illustrates result of the pilot experiment on UDS retention. An inverse relationship occurred between the values of UAF and the amount of UDS accumulated in the adsorbent (reflected by $W_{d}$ ). The end product weighed $1.65 \mathrm{~g}\left(30^{\circ} \mathrm{C}, 64 \% \mathrm{RH}\right)$ on average, gained $\sim 65 \%$ compared with the initial. The total reduction in UAF was $\sim 48 \%$, while the difference in net urine absorption $\left(W_{u}\right)$ was $\sim 17 \%$.

The experiment was halted on day 7 due to humidity accumulation in the adsorbent. The presence of both hydrate salts and complex compounds from the urine had affected [19]. Apparently, the pore structure played a functional role in liquid absorption, while the physical properties of the precipitates determined the efficiency 


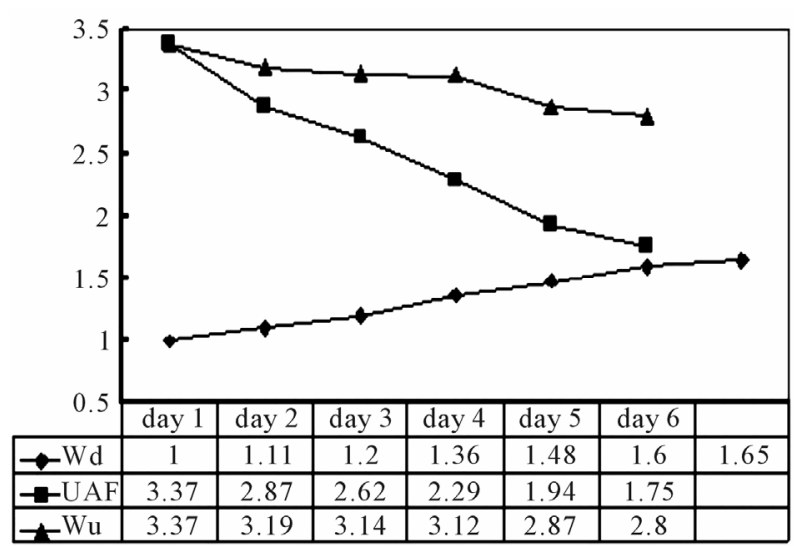

Figure 4. Urine absorption and urine TDS adsorption behaviours in DWH. $W_{u}$ : Urine absorbed (g); $W_{d}$ : Dried weight of the specimen (g).

and effectiveness of adsorption as well as the other well known factors. Figure 3(c) shows an SEM image of a UDS-DWH specimen. The pore walls are densely covered with diffused urine paste. The cubic particles represent, most possibly, the crystals of sodium chloride. No denaturation of the plant tissue was observed.

In normal adult humans, the value of urine specific gravity ranges from 1.001 to 1.030 [20]. Accordingly, the herein total mean urine absorption by DWH was 18.78 $\mathrm{ml} \cdot \mathrm{g}^{-1}$ on average, with $\sim 3.46 \%$ UDS retrieved.

Table 2 presents NPK levels measured for the UDSDWH specimens. P and K increased simultaneously with the amount of urine absorbed. Although the net amount of TN might have increased in the DWH regarding weight enhancement of the adsorbent over the time, it was still much smaller than the amount expected theoretically. The DWH's capacity of urine absorption declined from an initial $2.73 \mathrm{~L} \cdot \mathrm{kg}^{-1} \cdot \mathrm{d}^{-1}$ to $0.68 \mathrm{~L} \cdot \mathrm{kg}^{-1} \cdot \mathrm{d}^{-1}$, with a requirement of material change in about 25 effective days. The final $\mathrm{P}\left(\mathrm{P}_{2} \mathrm{O}_{5}\right)$ level in the adsorbent was shown to be $3.14 \%$, suggesting a satisfactory $\mathrm{P}$ recovery during the process.

Amino groups on the surface of a cellulose-based adsorbent played an important role in phosphate removal from solutions [25]. The carboxyl group of the cellulose in dried water hyacinth was also considered to be relevant [26]. In addition, the dry matter of water hyacinth petioles contained about $2.13 \% \mathrm{Ca}$ and $1.69 \% \mathrm{Mg}$ [27], which would also accelerate $\mathrm{P}$ adsorption by forming insoluble hydroxyapatite and struvite, i.e., $\mathrm{Ca}_{5}\left(\mathrm{PO}_{4}\right)_{3}(\mathrm{OH})$ and $\mathrm{NH}_{4} \mathrm{MgPO}_{4}$.

Dried water hyacinth displayed significant $\mathrm{K}$ loss when placed in biogas fluid in contrast to the constant $\mathrm{P}$ accumulation $[1,2]$. In the present experiment, however, the material was shown to be attractive to both elements, implying the involvement of different adsorption mechanisms. Although nitrogen makes up 20\% of UDS [23], it becomes decomposed into ammonia gas $\left(\mathrm{NH}_{2}\right)$ on exposure to air. This explains why both TN level and UDS accumulation in the present DWH samples were lower than mathematical expectations.

The experiment was suspended on day 6 as it began raining. Things came back normal about one week later. It took, however, 20 days for the absorption of other $8 \mathrm{~L}$ of the urine (Table 3). An average daily treatment was realized to be $\sim 1.1 \mathrm{~L} \cdot$ urine $\cdot \mathrm{kg}^{-1} \mathrm{DWH}$ during the effective days, and the maximum adsorption was $\sim 25 \mathrm{~L} \cdot$ urine $\cdot \mathrm{kg}^{-1}$ DWH.

It is worthy mentioned that a continuous direct sunlight exposure could have helped killing most forms of microorganism in the UDS-DWH. In addition, the ultraviolet radiation and infrared heat are known to be effective in the degradation of micropollutants [28]. The high sodium

Table 2. $\mathrm{NP}\left(\mathrm{P}_{2} \mathrm{O}_{5}\right) \mathrm{K}$ levels in the present UDS-DWH randomly sampled during experiment.

\begin{tabular}{|c|c|c|c|c|}
\hline & Initial & Day 1 & Days 1 - 5 & Days 1 - 33 \\
\hline Urine absorbed (L) & 0 & 1.0 & 4.0 & 12 \\
\hline Urine $P(g)$ expected $[21,22]$ & & $0.75-1.64$ & $2.98-6.56$ & $8.95-19.69$ \\
\hline Initial $\mathrm{P}(\mathrm{g})^{*}$ & & 2.02 & 2.02 & 2.02 \\
\hline $\mathrm{P}(\%)$ measured & 0.46 & 0.61 & 0.93 & 3.14 \\
\hline Urine $\mathrm{K}(\mathrm{g})$ expected $[23,24]$ & & $0.75-2.0$ & $3.0-8.0$ & $9.0-24.0$ \\
\hline Initial K $(\mathrm{g})^{*}$ & & 7.13 & 7.13 & 7.13 \\
\hline K $(\%)$ measured & 1.62 & 1.74 & 2.31 & 3.68 \\
\hline Urine N (g) expected [24] & & 11.2 & 44.8 & 134.4 \\
\hline Initial $\mathrm{N}(\mathrm{g})^{*}$ & & 17.25 & 17.25 & 17.25 \\
\hline TN (\%) measured & 3.92 & 2.81 & 3.62 & 3.98 \\
\hline
\end{tabular}

*initial content $(\%) \times 440 \mathrm{~g}(\mathrm{DWH})$. 
Table 3. The amounts of urine continuously absorbed by DWH during experiment.

\begin{tabular}{cccccc}
\hline & Days 1-5 & Days 6-13 & Days 14-18 & Days 19-28 & Days 29-33 \\
\hline Urine absorbed & $4 \mathrm{~L}$ & No job & $2.5 \mathrm{~L}$ & $4 \mathrm{~L}$ & $1.5 \mathrm{~L}$ \\
Ambient temperature & $29^{\circ} \mathrm{C}-33^{\circ} \mathrm{C}$ & $27^{\circ} \mathrm{C}-32^{\circ} \mathrm{C}$ & $29^{\circ} \mathrm{C}-35^{\circ} \mathrm{C}$ & $30^{\circ} \mathrm{C}-35^{\circ} \mathrm{C}$ & $30^{\circ} \mathrm{C}-36^{\circ} \mathrm{C}$ \\
Ambient humidity & $25 \%-40 \%$ & $66 \%-72 \%$ & $36 \%-58 \%$ & $25 \%-42 \%$ & $25 \%-38 \%$ \\
\hline
\end{tabular}

level raised by the urine deposit would also inhibit microbial growth in UDS-DWH.

\subsection{Field Application}

The male toilet involved in the field application of this research is currently used by two or three people during the weekdays and $8-10$ in the weekend. Since average urine production in adult humans is about $1-2 \mathrm{~L} \cdot \mathrm{d}^{-1}$ [23], the device is expected to serve well in about 60 effective days according to the herein revealed experimental results. Basically, it is economic and easy to handle in practice.

Human UDS contains high concentrations of plant nutrients. Urine $\mathrm{P}$ provides a soluble, plant-available form [29]. There are several ways to use UDS-DWH as a $\mathrm{P}(\mathrm{K})$-rich fertilizer. For example, the straws can be submerged in rice water in a weight ratio of about 1:100 1000 for direct spraying on the foliage of house plants. On the farm, they can be put in rain water for vegetable spraying to encourage prolific flowering and fruiting. Another research project is in plan to collect and provide information on fertilizer use of the UDS-DWH product.

\section{Conclusions}

This work demonstrated the feasibility of utilizing water hyacinth waste to convert source-separated human urine into a $\mathrm{P}(\mathrm{K})$-rich fertilizer. The present end product of UDS-DWH contained up to $3.14 \% \mathrm{P}_{2} \mathrm{O}_{5}$, which is commonly $0.075 \%-0.164 \%$ in fresh human urine, $\sim 0.4 \%$ in dried water hyacinth and $\sim 3 \%-8 \%$ in phosphate rock regarding the fraction available to plant [30]. The urine absorption in DWH was shown to be in a ratio of 25 (L) to $1(\mathrm{~kg})$ during 25 effective days through a continuous absorption/evaporation cycling. Compared with other intensive techniques concerning urine nutrient recovery, the present device is economic and convenient to operate in small farms.

In spite of its tremendous application in waste water treatment, water hyacinth proliferation is considered to be a significant economic and ecological burden to many sub-tropical and tropical regions of the world. In China, $10 \mathrm{~s}$ millions RMB a year are spent on removing the plants from infested water bodies, the waste transportation and landfill. Meanwhile, direct discharge of urine into water bodies in some rural areas has made eutrophi- cation worse and encouraged the spread of water hyacinth. In developed countries and areas, human urine typically contributes around $80 \%$ of the nitrogen, $50 \%$ of the phosphorus, and $90 \%$ of the potassium in the total nutrient load arriving at a treatment plant [31]. In conclusion, this proposed simultaneous utilization of both water hyacinth waste and source-separated human urine will benefit the environment from a wide range of perspectives.

\section{Acknowledgements}

This project was part of the Science and Technology Innovations Programme, executed and financially supported by the Fujian Academy of Agricultural Science. The authors are grateful to the Central Laboratory, Fujian Academy of Agricultural Sciences, for assistance on SEM and chemical analyses; to Xiamen Greenwave Biotechnology Co. Ltd. for assistance in preparing the DWH materials and to Mr. X. Gao for providing the site at \#3 Dongshan Guest Farm, Xiamen, to promote the present methodology innovation and its field application.

\section{REFERENCES}

[1] X. Chen, Z. Jiang, X. Chen, J. Lei, B. Weng and Q. Huang, "Use of Biogas Fluid-Soaked Water Hyacinth for Cultivating Pleurotus geesteranus," Bioresource Technology, Vol. 101, No. 7, 2010, pp. 2397-2400. doi:10.1016/j.biotech.2009.11.405

[2] X. Chen, X. Chen, X. Wan, B. Weng and Q. Huang, "Water Hyacinth (Eichhornia crassipes) Waste as an Adsorbent for Phosphate Removal from Swine Wastewater," Bioresource Technology, Vol. 101, No. 23, 2010, pp. 9025-9030. doi:10.1016/j.biotech.2010.07.013

[3] T. Mórrígan, "Peak Phosphorus: A Potential Food Security Crisis," University of California, Santa Barbara, 2010.

[4] T. Karak and P. Bhattacharyya, "Human Urine as a Source of Alternative Natural Fertilizer in Agriculture: A Flight of Fancy or an Achievable Reality," Resource, Conservation and Recycling, Vol. 55, No. 4, 2011, pp. 400-408. doi:10.1016/j.resconrec.2010.12.008

[5] J. R. Mihelcic, L. M. Fry and R. Shaw, "Global Potential of phosPhorus Recovery from Human Urine and Feces," Chemosphere, Vol. 84, No. 6, 2011, pp. 832-839. doi:10.1016/j.chemosphere.2011.02.046

[6] A. Panesar, "Overview of the Global Development of 
Ecosan," Proceedings of the DWA-BMZ-GTZ EcosanSymposium, Eschborn, 2006, 16 p.

[7] S. Antonini, S. Paris, T. Eichert and J. Clemens, "Nitrogen and Phosphorus Recovery from Human Urine by Struvite Precipitation and Air Stripping in Vietnam," Clean Soil Air Water, Vol. 39, No. 12, 2011, pp. 10991104. doi:10.1002/clen.201100036

[8] B. Lind, Z. Ban and S. Bydén, "Nutrient Recovery from Human Urine by Struvite Crystallization with Ammonia Adsorption on Zeolite and Wollastonite," Bioresource Technology, Vol. 73, No. 2, 2000, pp. 169-174. doi:10.1016/S0960-8524(99)90157-8

[9] M. Maurer, W. Pronk and T. A. Larsen, "Treatment Process for Source-Separated Urine," Water Resource, Vol. 40, No. 16, 2006, pp. 3151-3166. doi.org/10.1016/j.watres.2006.07.012

[10] K. G. Harry and A. Johnson, "A Non-Destructive Technique for Measuring Ceramic Porosity Using Liquid Nitrogen," Journal of Archaeology Science, Vol. 31, No. 11, 2004, pp. 1567-1575. doi:10.1016/j.jas.2004.03.020

[11] J. A. Salzman, E. T. Sullivan, J. R. Neetzel and C. J. Shiue, "The Water Holding Capacity of Wood Chips as Compared with Common Livestock Beddings," Minnesota Forestry Notes 69, School of Forestry, University of Minnesota, 1958.

[12] S. Molnar and B. Wright, "Evaluating Performance of Several Horse Beddings," Ontario Ministry of Agriculture, Food and Rural Affairs, 2006.

[13] R. M. Davies and U. S. Mohammed, "Moisture-Dependent Engineering Properties of Water Hyacinth Parts," Singapore Journal of Scientific Research, Vol. 1, No. 3, 2011, pp. 1-11.

[14] S. M. Zabihzadeh, "Water Uptake and Flexural Properties of Natural Filler/HDPE Composites," BioResource, Vol. 5, No. 1, 2010, pp. 316-323.

[15] R. C. Weast, "CRC Handbook of Chemistry and Physics," 58th Edition, CRC Press Inc., Palm Beach, 1978.

[16] D. E. Smiles, "Temperature Effects on Water Absorption by Three Different Porous Materials," Soil Research, Vol. 43, No. 4, 2005, pp. 533-540. doi:10.1071/SR04121

[17] S. A. Grant and J. Bachmann, "Effect of Temperature on Capillary Pressure," In: P. A. C. Raats, D. E. Smiles and A. W. Warrick, Eds., Contributions to Environmental Mechanics: A Tribute to John Philip, Geophysical Monographs Series, American Geophysical Union, Washington DC, 2002, pp.199-212.

[18] K. Chojnacka, "Biosorption of Cr (III) Ions by Wheat Straw and Grass: A Systematic Characterization of New Biosorbents," Polish Journal of Environmental Studies, Vol. 15 , No. 6, 2006, pp. 845-852.

[19] M. M. Pahore, R. Ito and N. Funamizu, "Rational Design of an Onsite Volume Reduction System for Source-
Separated Human Urine," Environmental Technology, Vol. 31, No. 4, 2010, pp. 399-408. doi:10.1080/09593330903505654

[20] Wikipedia, "Urine Specific Gravity," Wikipedia, the Free Encyclopedia, 2012. http://en.wikipedia.org/wiki/Urine_specific_gravity

[21] K. Gethke, H. Herbst and J. Pinnekamp, "Human UrineDecomposition Processes and Nutrient Recovery," Resource, Conservation and Recycling, Vol. 55, No. 4, 2011, pp. 400-408. doi:10.1016/j.resconrec.2010.12.008

[22] C. X. Yin, F. J. Huo and P. Yang, "Qualitative and Quantitative Determination of Inorganic Phosphate from $\mathrm{Hu}$ man Urine and Serum by Yb(III) Ion and Pyrocatechol Violet," Chemical Journal of Chinese Universities, Vol. 27, 2006, pp. 1849-1852.

[23] Wikipedia, "Urine," Wikipedia, the Free Encyclopedia, 2011. http://en.wikipedia.org/wiki/Urine

[24] M. Wolgast, "Rena Vatten. Om Tankari Kretslopp," Uppsala, Creamon HB, 1993.

[25] T. S. Anirudhan and P. Senan, "Adsorption of Phosphate Ions from Water Using a Novel Cellulose-Based Adsorbent," Chemical Ecology, Vol. 27, No. 2, 2011, pp. 147 164. doi: $10.1080 / 02757540.2010 .547487$

[26] M. Ibrahim, O. Kuhn and T. Scheytt, "Molecular Spectroscopic Study of Water Haycinth Dry Matter," The Open Chemical Physics Journal, 2009, Vol. 2, pp. 1-6. doi:10.2174/1874412500902010007

[27] M. F. Abdel-Sabour, "Water Hyacinth: Available and Renewable Resource," Journal of Environmental, Agricultural and Food Chemistry, Vol. 9, 2010, pp. 17461759.

[28] S. Antonini, P. T. Nguyen, U. Arnold, T. Eichert and J. Clemens, "Solar Thermal Evaporation of Human Urine for Nitrogen and Phosphorus Recovery in Vietnam," Science of the Total Environment, Vol. 414, 2012, pp. $592-$ 599. doi:10.1016/i.scitotenv.2011.11.055

[29] H. Kirchmann and S. Pettersson, "Human Urine-Chemical Composition and Fertilizer Use Efficiency," Fertilizer Research, Vol. 40, No. 2, 1995, pp. 149-154. doi:10.1007/BF00750100

[30] G. Rehm, M. Schmitt, J. Lamb, G. Randall and L. Busman, "Phosphorous in the Agricultural Environment," University of Minnesota Extension, 2010, http://www.extension.umn.edu/distribution/cropsystems/d c6288.html

[31] T. A. Larsen, I. Peters, A. Alder, R. Eggen, M. Maurer and J. Muncke, "Re-Engineering the Toilet for Sustainable Wastewater Management," Environmental Science and Technology, Vol. 35, No. 9, 2001, pp. 192A-197A. doi:10.1021/es012328d 